\title{
Application of Pop Up Book Media to Optimize Science Learning Outcomes
}

\author{
Aniq Amalia ${ }^{1}$, Dewi Setiyawati2* \\ ${ }^{1}$ Departement Magister Primary Teacher Education, UIN Sunan Kalijaga Yogyakarta, Indonesia \\ ${ }^{2}$ Madrasah Ibtidaiyah Asysyafi'iyyah Kabupaten Semarang, Jawa Tengah, Indonesia \\ Coressponding Author. E-mail: \\ 1aniqamalia6@gmail.com \\ 2dewisetiyawatidewi@gmail.com
}

Received: January 2nd, 2020

Accepted: July 26st, 2020

Online Published: July 28th 2020

\begin{abstract}
Science Learning in MI Ma'arif Kumpulrejo 02 Salatiga has not used a variety of active and creative learning media. This causes students to be passive and the lack of student attention to the material delivered by the teacher. Evidenced by the low learning outcomes of students who have not yet reached the KKM determined by the school 65. The purpose of this study was to determine the increase in science learning outcomes through Pop-Up book media in class IV MI Ma'arif Kumpulrejo 02 Salatiga. This research is a classroom action research conducted in three cycles, namely Cycle I, Cycle II, and Cycle III. Each cycle consists of four stages, namely planning, implementing, observing, and reflecting. The subjects of this study were class IV students, totaling 28 students. Data collection methods are interviews, observation, and documentation. The results of the study stated that the results of the first cycle of completeness student learning outcomes amounted to 39.29\% (11 students completed KKM). These results have not yet reached the indicator of success, which is $\geq 85 \%$ so that it is continued in the second cycle. Cycle II completeness of student learning by $64.29 \%$ (18 students completed KKM) so that from cycle I to cycle II increased learning outcomes by $25 \%$. How ever, in cycle II it still does not meet the indicators of success so it needs to be continued on cycle III. Cycle III completeness of student learning by $85.71 \%$ ( 24 students completed KKM). In this third cycle student learning outcomes have met the indicator of learning success that is $85 \%$. Thus, it can be concluded that the application of Pop-Up book media can improve the learning outcomes of science in class IV MI Ma'arif Kumpulrejo 02 Salatiga.
\end{abstract}

Keywords: Pop-Up book Media, Learning Outcomes

How to cite this article :

Amalia, A., \& Setiyawati, D. (2020). Application of Pop Up Book Media to Optimize Science Learning Outcomes. IJIS Edu : Indonesian Journal of Integrated Science Education, 2(2), 143-151. doi:http://dx.doi.org/10.29300/ijisedu.v2i2.3018 


\section{INTRODUCTION}

The Education is a field of information delivery and a process that needs to be corrected and cleaned out of things that will spoil the formation of self and the whole of the student (Hamdan, Samian , \& Muslim, 2018). The teaching and learning process is essentially the process of delivering communication, where the teacher acts as a messenger and students as recipients of the message. The message conveyed by the teacher in the form of contents or teachings poured on a symbol both verbal (words and writing) and non-verbal (Permana, Johar, \& Bunyamin, 2014). Subjects taught at Elementary School (SD) or Madrasah Ibtidaiyah (MI) one of which is the subject of Natural Sciences (IPA). Natural Sciences is a family of science that has special characteristics, namely studying natural phenomena that are factual in the form of reality or events and causal relationships (Wisudawati \& Sulistyowati, 2014). Natural Sciences plays an important role in human life. This is because life is very dependent on nature. Science education is one of the subjects in the school that plays an important role in shaping the character of qualified students, because natural science is a means of thinking to study everything that can occur in a student's life experience in his daily life, for that there needs to be an increase the quality of educators in the field of science. One thing that must be considered is the increase in science learning outcomes of students in school. Sudjana revealed that learning outcomes are abilities students have after they have received their learning experience (Jihad \& Haris, 2013). Science learning outcomes can be achieved by students if the teacher is able to generate student motivation (Durandt, tt: 143). To achieve satisfactory learning, especially in natural science learning, there must be an appropriate learning model or approach (Rini, 2020). The main material in science lessons in class IV one of which is animals based on food. In teaching the material the teacher must always be creative and innovative in teaching so that students more easily understand the material being taught and be enthusiastic in participating in the teaching and learning process (Maman \& Rajab, 2016). Teachers are the people who have the most role in creating quality human resources who can compete in an age of rapid technological development (Juita, 2019). Teachers are people who are rich in experience and knowledge, with the knowledge they have will produce intelligent students (Kristiantari, 2015). Teachers are required to always be creative in creating ideas in designing new learning systems that are able to make students achieve their learning goals with full meaning (Safri, Sari, \& Marlina, 2017).

Based on observations in the field that the problem of learning science materials of various animals based on the type of food can not be fully understood by students, students are still difficult to distinguish between animals classified as omnivorous, herbivorous, and carnivorous. Natural Science learning in MI Ma'arif Kumpulrejo 02 Argomulyo District Salatiga is only teacher centered where the teacher only explains a material concept and students are given training through student worksheets. Learning activities like this cause students to be passive and less creative in learning. Learning media is only written in the learning implementation plan, without further action. This is evident that the existence of learning media contained in the MI is only limited to a display full of dust. Conventional learning without the support of a media makes students passive and student learning outcomes are low on natural science subjects various kinds of animals based on the type of food. The data shows that only 28 students 11 students $(39.29 \%)$ can achieve the Minimum Mastery Criteria (KKM) with an average value of 56.07 with the KKM value of science subjects is 65 .

Based on the above problems, each teacher can apply ways to make learning more interesting, including by using learning media. Learning activities cannot be separated from the media which is a means to achieve learning objectives (Izza \& Wijayanti, 2017). Learning media as a tool for teaching and learning process can be used to stimulate thoughts, feelings, attention, and the ability or learning skills so that it can encourage a better learning process. As expressed by that the learning media can be realized by many education practitioners very helpful in the learning process activities both inside and outside the classroom, especially helping improve student achievement (Munadi, 2008).

One of the media that can be used to improve science learning outcomes is the PopUp book media. Dzuanda (2011) explains the meaning of Pop-Up book is a book that has a movable part or has 3 (three) dimensions as well as provides a more interesting visualization of the story from the display of images that can move when the page is opened. Pop-up books are 
media that use paper engineering (Ningtiyas, Setyosari, \& Hendy, 2019). Devi \& Maisaroh (2017) revealed that Pop-Up book media can convey a variety of stories, ranging from knowledge such as animal recognition, the geographical location of a country, culture, history, religious activities, to imaginary stories such as fairy tales, fables, engineering stories that are now increasingly popular and developing in Indonesia. The selection of Pop-Up book media, in addition to being in accordance with the conditions of students, is also considered to be more interesting compared to before using only sheets of student books. The use of Pop-Up book media can motivate students to understand the contents of learning material because in the PopUp book media there are illustrated illustrated story stories that look more interesting and if the media is used can provide surprises on each page so as to increase the child's imagination in understanding the contents material of the book.

Previous research on pop-up books that support this research was conducted by Poonsri (2012) with the title "An Augmented Reality 3D Pop-Up Book: the Development of a Multimedia Project for English Language Teaching". The results of his research in a class that was given treatment can improve learning outcomes effectively. In addition, research conducted by Sylvia (2015) entitled "The Effect of the Use of Pop-Up Book Media on Narrative Writing Skills of Elementary School Students". The results showed that there were significant differences between student learning outcomes before treatment and after treatment.

The stage of using Pop-Up book media according to (Sardiman, 2006) there are three stages, namely preparation before using (this stage needs to be done to support the use of media so that it runs smoothly by studying the instructions on how to use the Pop-Up book media, and prepare media equipment that will be used in the activities of the learning process); activities during use (this stage of use requires a comfortable and quiet room, so that in the process of learning activities do not experience disturbances that can interfere with the attention and concentration of students. Students at this stage are introduced to various animals based on the type of food); and follow-up on the use of Pop-Up book media (used to strengthen students' understanding of the material delivered through Pop-Up book media, and provide an evaluation of learning outcomes).

\section{RESEARCH METHOD}

The research method used was PTK (Classroom Action Research). Classroom Action Research is an observation in the form of actions towards learning activities that are deliberately raised and occur in a class simultaneously (Suyadi, 2014). Arikunto, Suhardjono, \& Suparti (2014) describe four stages in the implementation of CAR, namely (1) planning, (2) implementation, (3) observation, and (4) reflection. The subjects of this study were grade IV MI Ma'arif Kumpulrejo 02 Salatiga students.

Data collection in this study uses the method of (1) observation to observe data related to student activity in the learning process, and (2) formative tests to get data on the improvement of learning outcomes obtained by students so that they can measure the ability and understanding of students in learning (Mulyasa, 2011).

The indicator of learning success is if classically $\geq 85 \%$ of students complete learning, the cycle is stopped. Formula for calculating the percentage of classical completeness:

$$
\mathrm{P}=\frac{x}{x i} \times 100 \% \text { (Daryanto, 2011) }
$$

\section{RESULTS AND DISCUSSION Initial Condition}

Science learning in schools is still teacher centered where the teacher only explains a material concept and students are given training through student worksheets. Learning activities like this cause students to be passive and less creative in learning. Learning media is only written in the learning implementation plan, without further action. In the material types of animals based on food the average value achieved by students reached only 50.89 of the number of grade IV students. Students who have finished learning to reach the KKM limit are 4 students with a percentage of $14.29 \%$, while students who have not yet completed are 24 students with a percentage of $85.71 \%$. At this pre-cycle classically learning cannot be said to be complete because students who get a value of $\geq 65$ (KKM score) only reach $14.29 \%$ of the total number of students. The percentage results in the pre cycle have not yet reached the indicator of success which is $\geq 85 \%$. Therefore it is necessary to have an innovation in learning activities both innovation from the way of teaching teachers or innovation from the learning source itself. As revealed by Masturah, Mahadewi, and Simamora (2018) that is by using pop up book media. 


\section{Cycle I}

The learning process in Cycle I begins with the teacher presenting various kinds of animal material based on the food type of herbivores using Pop-Up media. Then divide students into groups. The teacher distributes various kinds of pictures of animals to each group. Students are asked to find some pictures of herbivorous animals and paste them on the paper provided. The teacher asks one of the group members to present their work in front of the class. Other groups are given the opportunity to ask questions.
The implementation of learning using Pop-Up media in Cycle I has not been implemented well, because the teacher does not pay attention to student activities, because during the discussion there were some students who used media but were not used well.

This study aims to determine the increase in learning outcomes using the Pop-Up Book media so that at the end of the learning cycle, students are given test questions to work on. There are 11 students who have achieved KKM grades and 17 students who have not yet reached KKM

Table 1. Recapitulation of Cycle I Student Learning Outcomes

\begin{tabular}{clc}
\hline No. & \multicolumn{1}{c}{ Information } & Results \\
\hline 1. & Highest score & 85 \\
2. & Lowest value & 40 \\
3. & Studets complete learning & 11 \\
4. & Students have not yet finished studying & 17 \\
5. & Grade average & 56,07 \\
6. & Percentage of classical completeness & $39,29 \%$ \\
\hline
\end{tabular}

Based on the table 1 that the average value achieved by students in Cycle I only reached 56.07 of the number of grade IV students. Students who have finished learning to reach the KKM limit are 11 students with a percentage of $39.29 \%$, while students who have not yet completed are 17 students with a percentage of $60.71 \%$. In Cycle I, classically learning cannot be said to be complete because students who get a value of $\geq 65$ ( $\mathrm{KKM}$ value) only reach $39.29 \%$ of the total number of students. Learning in cycle I still has to be improved in cycle II. How to overcome obstacles in the first cycle researchers with the teacher conduct discussions to plan improvements in the second cycle. This is done so that in the next cycle the same weakness does not occur again. The improvement plan is that the teacher should invite students to actively participate in using the media, so that students are expected to be able to better understand the material and practice the courage of students to speak in front of the class, besides that the PopUp Book media will be more useful.

\section{Cycle II}

Cycle II research has proceeded better than Cycle I. In Cycle II the teacher has appointed a number of students who are passive to come forw ard to explain the material using the Pop-Up Book, but there are still many students who are embarrassed to come forward. This is still an obstacle to achieving the classical value expected by researchers. Teachers should give more exercises to students to speak in front, with the practice expected students can get used to speaking in public and dare to sharpen mentally to think. At the end of the second cycle of learning, students were given the evaluation test questions as in cycle I. The results of the test contained 10 students achieving the KKM score and 5 students had not yet reached the KKM

Table 2. Recapitulation of Cycle II Student Learning Outcomes

\begin{tabular}{clc}
\hline No. & \multicolumn{1}{c}{ Information } & Results \\
\hline 1. & Highest score & 90 \\
2. & Lowest value & 45 \\
3. & Studets complete learning & 18 \\
4. & Students have not yet finished studying & 10 \\
5. & Grade average & 68,92 \\
6. & Percentage of classical completeness & $64,29 \%$ \\
\hline
\end{tabular}


Based on the table shows that the average value achieved by students in Cycle II is 68.92 of the total number of grade IV students. Of this number, students who have finished learning are 18 students $64.29 \%$, while those who have not finished learning there are 10 students $35.71 \%$. Classically, learning in Cycle II also has not yet reached the specified minimum completeness limit of $85 \%$. This is the main reason for researchers to continue research in Cycle III.

\section{Cycle III}

Research in cycle III went well than in the previous cycle. Weaknesses in cycle II were successfully corrected in learning cycle III. Learning in cycle III can take place as planned. At the end of learning cycle III, students are given an evaluation test questions as in cycle I and cycle II. The test results show that there are 24 students achieving the KKM score and 4 students have not yet reached the KKM

Table 3. Recapitulation of Cycle III Student Learning Outcomes

\begin{tabular}{clc}
\hline No. & \multicolumn{1}{c}{ Information } & Results \\
\hline 1. & Highest score & 100 \\
2. & Lowest value & 55 \\
3. & Studets complete learning & 24 \\
4. & Students have not yet finished studying & 4 \\
5. & Grade average & 80,27 \\
6. & Percentage of classical completeness & $85,71 \%$ \\
\hline
\end{tabular}

Based on these data shows that learning in Cycle III has been considered complete because it has reached the minimum limit of classical completeness that has been determined that is $85 \%$. This is the main reason for researchers to stop the research process in Cycle III. Students who have not yet finished studying in Cycle III will be given independent actions in the form of exercises or remedial monitored by the teacher.

Learning by using Pop-Up book media is proven to improve student learning outcomes. As the results of research conducted by Ningtiyas, et al (2019) that the Pop Up Book media can improve the learning outcomes of Natural Sciences. Pop Up Book media used in this study can be seen in Figure 1

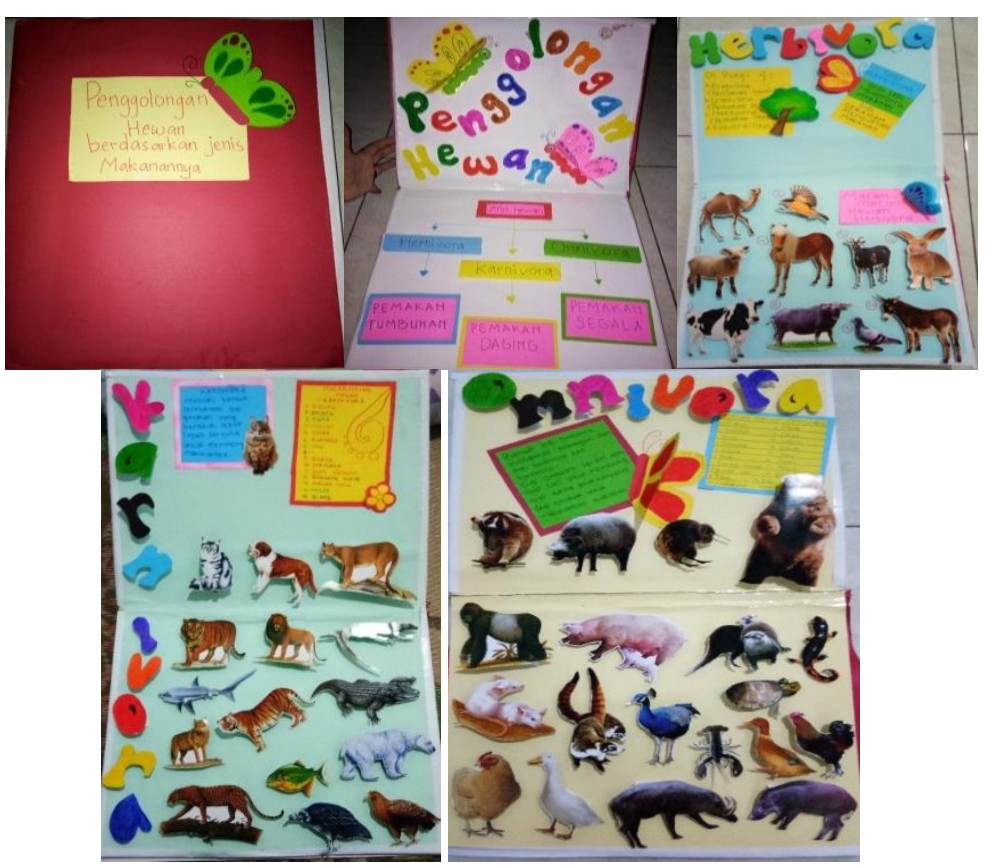

Figure 1. Pop Up Book Media 
The mastery of student learning outcomes using the Pop-Up book media is evidence of the successful use of the learning media. The value of the recapitulation of Cycle I, Cycle II, Cycle III can be seen in Table 4

Table 4. Recapitulation Value of Cycle I-Cycle III

\begin{tabular}{|c|c|c|c|c|}
\hline Cycle & Average & Category ategor & Total & $\begin{array}{l}\text { Percentage } \\
\text { Per }\end{array}$ \\
\hline \multirow{2}{*}{ I } & \multirow{2}{*}{56,07} & Complete & 11 & $39,29 \%$ \\
\hline & & Not Complete & 17 & $60,71 \%$ \\
\hline \multirow{2}{*}{ II } & \multirow{2}{*}{68,92} & Complete & 18 & $64,29 \%$ \\
\hline & & Not Complete & 10 & $35,71 \%$ \\
\hline \multirow{2}{*}{ III } & \multirow{2}{*}{80,17} & Complete & 24 & $85,71 \%$ \\
\hline & & Not Complete & 4 & $14,29 \%$ \\
\hline
\end{tabular}

It can be seen that the results of student learning in Cycle I there are 11 students $(39.29 \%)$ completing learning and 17 students $(60.71 \%)$ who have not yet completed study with an average grade of 56.07. Based on these results, it means that learning in Cycle I has not met the specified completeness criteria. Then the researcher must continue the research in Cycle II with different material and time.

Learning outcomes in Cycle II obtained data on 18 students (64.29\%) completing learning and 10 students $(35.71 \%)$ not completing learning with an average value of 68.92. Based on the acquisition of these values, it can be seen that the learning outcomes from Cycle I to Cycle II an increase of $25 \%$. This increase still does not meet the specified classical completeness criteria. Researchers must continue their research in Cycle III with different material and time.

Learning outcomes in Cycle III obtained 24 students $(85.71 \%)$ completed learning and 4 students $(14.29 \%)$ had not finished learning with an average value of 80.17. Based on data obtained from the implementation of Cycle III research, it can be seen that the results from Cycle II to Cycle III have increased by $21.42 \%$. The implementation of learning in Cycle III has fulfilled the established completeness criteria, which is $\geq 85 \%$ of the total 33 students who have completed their study. The results of the Cycle III study were the reason researchers stopped their research.

Based on Table 4 above can be illustrated in Figure 2 bar diagram.

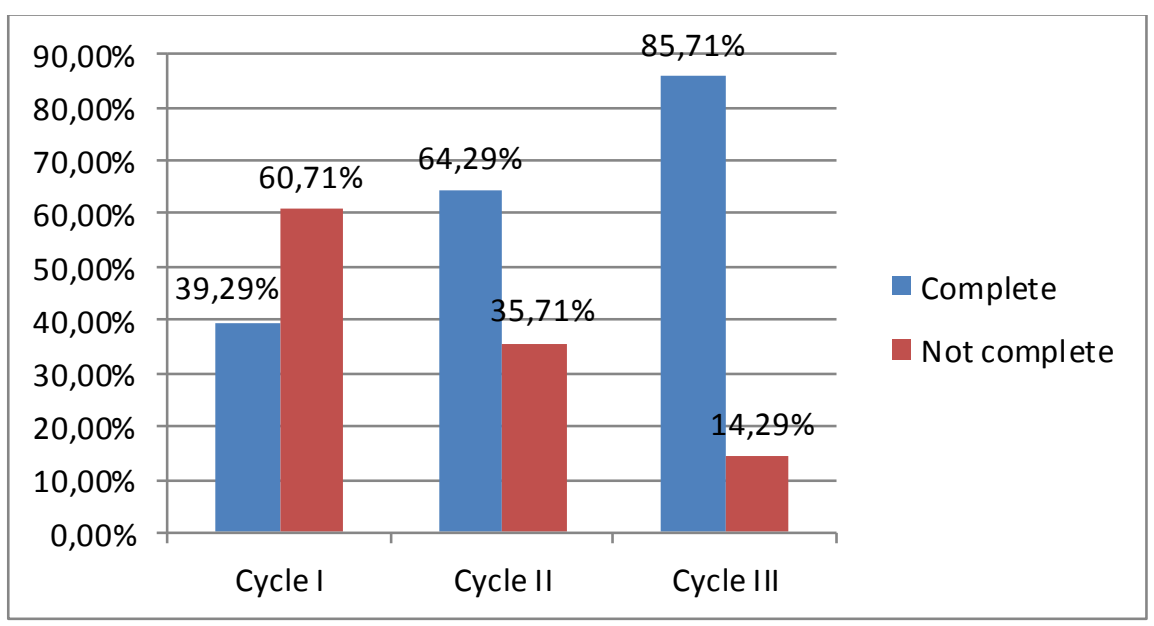

Figure 2. Percentage Graph of Student Learning Outcomes 
Figure 2 shows that student learning outcomes after applying the use of learning media in the form of Pop-Up books increased from Cycle I 39.29\% of students completing learning, Cycle II $64.29 \%$ of students completing learning, and Cycle III $85.71 \%$ of students completing learning . The increase in students who have finished learning from Cycle I to Cycle II is $25 \%$ and Cycle II to Cycle III is $21.42 \%$.

Based on the discussion above, the recapitulation of the increase in student learning outcomes Cycle I - Cycle III can be seen in Figure 3 in the form of a line diagram below.
Based on this discussion, this study is in line with research conducted by (Domitila, Yeni, \& Titin, 2017) namely pop-up book media can increase student motivation and achievement because this media has advantages such as there are surprises on each page, has a threedimensional element, and easy to open so students are enthusiastic. This is also expressed by Khoirunnisa \& Yusman (2015) that the pop-up book media can increase student motivation and learning achievement so that it becomes one of the media that can help the learning process.

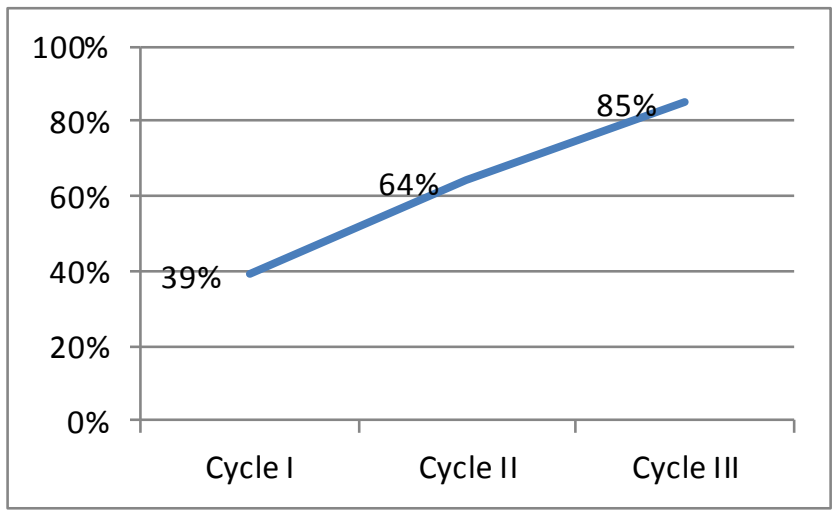

Figure 3. Recapitulation of Learning Outcomes with Line Diagrams

\section{CONCLUSION}

Based on the results of research conducted in class IV MI Ma'arif Kumpulrejo 02 Salatiga, it can be concluded that the application of Pop-up Book media can improve the learning outcomes of natural science material of various animals based on the type of food. Student learning outcomes in the first cycle of students who have reached mastery learning by $39.29 \%$ (11 students complete KKM). Cycle II mastery learning was 64.29\% (18 students completed KKM). Cycle III mastery learning reaches $85.71 \%$ (24 students complete KKM). The learning outcomes achieved by students in Cycle III $85.71 \%$ so that this CAR was declared stopped because it had met the classical completeness criteria, namely $\geq$ $85 \%$ of students completed KKM.

The learning process on the material of various animals based on the type of food in class
IV MI Ma'arif Kumpulrejo 02 Salatiga in each cycle can be done well. This is evidenced by an increase in mastery learning each cycle. The increase from Cycle I to Cycle II was 25\% and the increase from Cycle II to Cycle III was $21.42 \%$. process.

\section{REFERENCES}

Arikunto, Suharsimi, Suhardjono dan Suparti. (2014). Penelitian Tindakan Kelas. Jakarta: PT Bumi Aksara.

Daryanto. (2011). Penelitian Tindakan Kelas dan Penelitian Tindakan Sekolah. Yogyakarta: Gava media. 
Devi, Anggit Shinta \& Maisaroh, Siti. (2017). Pengembangan Media Pembelajaran Buku Pop Up Wayang Tokoh Pandhawa pada Mata Pelajaran Bahasa Jawa Kelas V SD. Jurnal PGSD Indonesia, 3(2).

Domitila, Ressi., Yeni, Laili Fitri., \& Titin. (2017). Kelayakan Pop-Up Book Keragaman Jamur di Hutan Lindung Gunung Naning pada Materi Keanekaragaman Hayati. Artikel Program Studi Pendidikan Biologi FKIP Untan Pontianak, hlm 1-9.

Durant, Sri Winarti., Said, I., \& Ratman. (tt). Meningkatkan Hasil Belajar IPA Khususnya Materi Energi dan Perubahannya melalui Pembelajran Quantum Teaching di Kelas V SDN Inpres Matamaling. Jurnal Kreatif Tadulako, 2(3), 142-153.

Dzuanda. (2011). Design Pop Up Child Book Puppet Figures Series Gatotkaca. Jurnal Library ITS Undergraduate. (Http:/ / library.its.undergraduate.ac.id. Diunduh 20 Maret 2020)

Hamdan, Nur Asyikin., Samian, Abdul Latif., \& Muslim, Nazri. (2018). Islamic Science Paradigm Is A Science and Religious Integration. International Journal of Civil Engineering and Tecbnology, 9 (10), 12981303.

Izza, Erika Nuril, \& Wijayanti, Arfilia. (2017). Pengembangan Media Biyas Mata Pelajaran IPA Kelas V di Sekolah Dasar. Jurnal Pendidikan Sekolah Dasar, 4(1), 63-68.

Jihad, A., \& Haris, A. (2013). Evaluasi Pembelajaran. Yogyakarta: Multi Pressindo.

Juita, Ratna. (2019). Meningkatkan Hasil Belajar IPA melalui Metode Eksperimen pada Sisw a Kelas IV SDN 02 Kota Mukomuko. Indonesian J. Integr. Sci. Education (IJIS Edu ), 1(1), 43-50.
Khoirunnisa, O, A \& Yusman, W. (2015). Pengembangan Pop-Up Book Materi Kalor untuk Meningkatkan Motivasi dan Prestasi Belajar Peserta Didik Kelas VII. Jurnal Pendidikan Matematika dan Sains.

Kristiantari, M. R. (2015). Analisis Kesiapan Guru Sekolah Dasar dalam Mengimplemetasikan Pembelajaran Tematik Integratif Menyongsong Kurikulum 2013. JPI Jurnal Pendidikan Indonesia), 3(2), 460-470.

Maman, Mayong \& Rajab, Andi Aryani. (2016). The Implementation of Cooperative Learning Model Number Heads Together (NHT) in Improving the Students Ability in Reading Comprehension. International Journal of Evaluation and Research in Education, 5(2), 174-180.

Masturah, Elisa Diah., Mahadewi, Luh Putu Putrini., \& Simamora, Alexander Hamonangan. (2018). Pengembangan Media Pembelajaran Pop-Up Book pada Mata Pelajaran IPA Kelas III Sekolah Dasar. Jurnal EDUTECH Universitas Pendidikan Ganesha, 6(2), 212-221.

Mulyasa. (2011). Praktik Penelitian Tindakan Kelas. Bandung: PT Remaja Rosdakarya.

Munadi, Yudhi. (2008). Media Pembelajaran: Sebuah Pendekatan Baru. Jakarta: Gaung Persada Press.

Ningtiyas, Tri Wahyu., Setyosari, Punaji, \& Praherdiono, Hendy. (2019). Pengembangan Media Pop-Up Book untuk Mata Pelajaran IPA Bab Siklus Air dan Peristiwa Alam sebagai Penguatan Kognitif Siswa. Jurnal Kajian Teknologi Pendidikan, 2(2), 115-120.

Permana, Muhammad Shiddiq., Johar, Dhami., \& Bunyamin. (2014). Pengembangan Media Pembelajaran Interaktif Ilmu Pengetahuan 
Alam (IPA) Berbasis Multimedia. Jurnal Algoritma, 11(2), 254-263.

Poonsri. (2012). An Augmented Reality 3D Popup Book: the Development of a Multimedia Project for English Language Teaching. IEEE International Conference on Multimedia and Expo. DOI 101109/ICME. Thailand: Assumption University.

Rini, Endah Setia. (2020). The Effect of Problem Based Learning on Cognitive Outcome in Science Subject in Junior High School : Topic Water Pollution. IJIS Edu:Indonesian J. Integr. Sci. Education, 2(2), 108-113.

Safri, Meilia., Sari, Sri Adelila., \& Marlina. (2017). Pengembangan Media Belajar Pop Up Book pada Materi Minyak Bumi. Jurnal Pendidikan Sains Indonesia, 05(01), 107-113.

Sardirman. (2009). Interaksi dan Motivasi Belajar Mengajar. Jakarta: Rajaw ali Press.

Suyadi. (2014). Panduan Penelitian Tindakan Kelas. Jogjakarta: Diva Press.

Sylvia, Nur Indah \& Hariani, Sri. (2015). Pengaruh Penggunaan Media Pop-Up Book terhadap Keterampilan Menulis Narasi Siswa Sekolah Dasar. Jurnal Pendidikan Guru SD, 03(02).

Wisudawati, A. W. \& Sulistyowati, E. (2014). Metodologi Pembelajaran IPA. Jakarta: Bumi Aksara. 